\title{
WOJSKO JAKO INTERNOWANIE
}

\section{FORMY REPRESJI W CZASIE STANU WOJENNEGO 1982-1983 WOBEC DZIAŁACZY OPOZYCJI ANTYKOMUNISTYCZNEJ UMIESZCZONYCH W WOJSKOWYCH OBOZACH SPECJALNYCH}

(CZ. 1)

\section{$\overline{\overline{2}}$ \\ Elwira Brodecka}

\section{WSTĘP}

W okresie Polskiej Rzeczypospolitej Ludowej władza stosowała różnorodne formy represji. Jedną z nich było masowe internowanie do wojska, głównie działaczy tzw. drugiego garnituru „Solidarności” oraz osób, których nie można było skierować do więzień ze względu na brak dowodów „wrogiej działalności”'. Decyzję o wprowadzeniu w życie tej formy represji podjęły peerelowskie ministerstwa: Spraw Wewnętrznych i Obrony Narodowej w ścisłej współpracy ze Służbą Bezpieczeństwa. Ogólne ustalenia zawarte w szyfrogramie płk. Józefa Sasina do zastępców komendantów wojewódzkich Milicji Obywatelskiej ds. SB, dotyczące m.in. poboru osób o kategorii A niebędących jedynymi żywicielami rodzin itd., w praktyce nie były w ogóle przestrzegane.

12 grudnia 1981 r. w całej Polsce już od godz. 23.30 trwała akcja „Jodła”, która miała na celu internowanie wcześniej wytypowanych działaczy „Solidarności”

Artykuł jest zmienioną wersją pracy licencjackiej napisanej pod kierunkiem dr. hab. Janusza Mierzwy i obronionej w $2016 \mathrm{r}$. 
i przejęcie kontroli nad siedzibami związku. W wyniku tej akcji internowano ponad 3 tys. osób, w tym zatrzymano większość członków Komisji Krajowej. Skuteczność aresztowań wynosiła 95-100\%, co stanowiło pierwszy sukces autorów stanu wojennego.

Akcji „Jodła” towarzyszyła mniej znana, a równie niebezpieczna akcja „Klon”. Polegała ona na przeprowadzaniu tzw. rozmów profilaktyczno-ostrzegawczych. Działaczom związkowym i opozycjonistom przedstawiano do podpisania deklarację lojalności, czyli zobowiązanie do zaprzestania działalności związkowej i pełnego podporządkowania się przepisom stanu wojennego oraz postanowieniom władz. Podpisanie „lojalki” było krytykowane przez podziemie solidarnościowe, ale nie miało nic wspólnego z tajną współpracą, choć bardzo często stanowiło dla bezpieki podwaliny do jej nawiązania. Do początku $1982 \mathrm{r}$. przeprowadzono 6,5 tys. takich rozmów, z których udało się pozyskać 5,6 tys. deklaracji lojalności, zaś ponad 900 osób podjęło tajną współpracę².

Osoby, które nie zgodziły się na współpracę, umieszczano w przygotowanych wcześniej ośrodkach dla internowanych lub w wydzielonych częściach więzieńn W pierwszych dniach stanu wojennego funkcjonariusze MO i SB aresztowali na terenie całego kraju około 5 tys. działaczy NSZZ „Solidarność”, NSZZ Rolników Indywidualnych „Solidarność, a także innych osób umieszczonych na uprzednio przygotowanych listach, które rozmieszczono w 49 ośrodkach odosobnienia ${ }^{4}$.

Większość internowanych stanowili działacze związkowi i ich doradcy, przedstawiciele opozycyjnych organizacji oraz struktur poziomych w partii. Zatrzymano również 32 członków poprzedniej ekipy władzy, m.in. Edwarda Gierka, Piotra Jaroszewicza, Edwarda Babiucha, Zdzisława Grudnia, Jerzego Łukaszewicza, których umieszczono w przeznaczonym specjalnie dla nich ośrodku nad Jeziorem Głębokim na Pojezierzu Pomorskim ${ }^{5}$.

Liczba internowanych ulegała ciągłym zmianom. Według informacji wiceministra spraw wewnętrznych gen. Bogusława Stachury z grudnia 1982 r. internowano łącznie 10131 osób, ale jednocześnie dłużej nie przetrzymywano więcej niż 5,3 tys. internowanych ${ }^{6}$.

Tematem niniejszego artykułu są dodatkowe represje stosowane wobec działaczy NSZZ „Solidarność” oraz opozycji antykomunistycznej w postaci internowania w tzw. wojskowych obozach specjalnych. Określenie to oznacza w tym

\footnotetext{
J. Rat ajc zak, Małopolska „Solidarność”. 1981-1989, cz. I, „Sowiniec” 2006, nr 29, s. 6-7.

Ibidem, s. 298.

D. Iw a e c zko, Stan wojenny, Rzeszów 2011, s. 5-6.

A.L. S ow a, Od Drugiej do Trzeciej Rzeczpospolitej (1945-2001), Kraków 2001, s. 298.

6 Ibidem.
} 
przypadku masowy pobór do wojska działaczy opozycyjnych w okresie stanu wojennego przeprowadzony na mocy decyzji MSW przy współpracy z SB.

W swojej pracy koncentruję się na poborze do wojska jako elemencie represji. Tego typu represje w PRL były stosowane już wcześniej, począwszy od lat 1949-1956, gdy w kraju przeprowadzano pobór do „zastępczej służby wojskowej”, która polegała na przymusowej pracy w śląskich kopalniach węgla ${ }^{7}$.

Obecny stan badań nad tym zagadnieniem jest niewyczerpujący. Informacje na temat obozów czerpałam z opracowań, gdzie poświęcono im stosunkowo niewiele miejsca, z akt znajdujących się w Archiwum Instytutu Pamięci Narodowej w Białymstoku, Bydgoszczy, Szczecinie i Warszawie. Materiały archiwalne, stanowiące wykazy osób wytypowanych do odbycia służby wojskowej, meldunki i akta śledztw zostały mi udostępnione za pośrednictwem Krakowskiego Oddziału Instytutu Pamięci Narodowej ${ }^{8}$. Przydatne okazały się również informacje zawarte w podziemnej prasie związkowej: „Biuletynie Łódzkim”, „Hutniku”, „Obserwatorze Wielkopolskim”, „Informatorze” (Lublin), „Solidarności. Informatorze Regionu Ziemi Sandomierskiej”, „Toruńskim Informatorze Solidarności”, „Tygodniku Mazowsze”, „Tygodniku Wojennym”, „Wiadomościach Podlaskich”. Tak obszerną kwerendę prasy związkowej zawdzięczam pomocy Leszka Jaranowskiego, który jest również autorem strony internetowej dotyczącej wojskowych obozów specjalnych (http://www.darpoint.pl/pages/wos.htm), z której też wielokrotnie korzystałam, głównie ze względu na zamieszczone tam relacje osób internowanych. Przy pisaniu mojej pracy posiłkowałam się również informacjami z pierwszej pracy poświęconej wojskowym obozom specjalnym autorstwa Marcina Dąbrowskiego ${ }^{9}$ oraz artykułami z tomu Inteligentna forma internowania opublikowanego w 2016 r. przez Instytut Pamięci Narodowej.

7 Szerzej zob.: E.J. Nale pa, Wojskowe bataliony górnicze w Polsce w latach 1949-1959, „Przegląd Historyczny” 1994, nr 1/2; Z. Woj d alski, Wojskowy Korpus Górniczy, „Dzieje Najnowsze” 1983, z. 3; R. Klem entowski, Skazani na uran. Kopalnie rudy uranu we wspomnieniach żotnierzy batalionów pracy, „Acta Universitatis Wroclaviensis. Studia nad Faszyzmem i Zbrodniami Hitlerowskimi” 2009, 31, s. 293-307; P. Piot row ski, Stużba wojskowa jako forma represji politycznej w ludowym Wojsku Polskim, [w:] Inteligentna forma internowania. Ćwiczenia i powołania do ludowego Wojska Polskiego jako forma represji po 13 grudnia 1981 r., red. G. Maj ch r zak, Warszawa 2016, s. 24-63.

8 Pozostała część materiałów archiwalnych IPN, na których bazowałam, dostępna jest w Internecie na stronie www.13grudnia81.pl.

9 M. Dąbrowski, Wojskowe obozy specjalne 1982-1983, Lublin 2013 (wersja skrócona: Wojskowe obozy internowania w Polsce w latach 1982-1983, [w:] Inteligentna forma internowania..., s. 64-76). 


\title{
2. POBÓR DO WOJSKA JAKO ELEMENT REPRESJI W DOBIE STANU WOJENNEGO
}

\begin{abstract}
W ostatnich dniach nastąpił zmasowany pobór członków „S” z naszego Kombinatu na ćwiczenia do wojska. Przypomina to czasy poprzedzające Powstanie Styczniowe w 1863 r., gdy rosyjski zaborca przez podobny pobór (zwany branką) do carskiej armii chciał przeszkodzić wybuchowi. Jak się okazało - daremnie ${ }^{10}$.
\end{abstract}

Ta zbieżność pokazuje, że początków sposobu internowania poprzez pobór do wojska można szukać w o wiele odleglejszych czasach. Oczywiście podobieństw między tymi wydarzeniami jest znacznie więcej - przede wszystkim mamy do czynienia z tym samym wrogiem, który tym razem działał rękoma swoich polskich popleczników. Wysyłanie wagonami w głąb Rosji przypominało również wysłanie rekrutów na służbę w 1982 r. do jednostek wojskowych, których nie było nawet na mapach, np. Czerwonego Boru, do którego powołany został Leszek Jaranowski, sam opisujący to miejsce następująco:

Czerwony Bór - nikt z nas nie wiedział, gdzie to jest. Na mapie tego nie było w ogóle. Co to za białe niedźwiedzie, jakieś takie? Potem się okazało, że to głęboko na północnym wschodzie. Między Łomżą a Zambrowem. Poligon wojskowy. Na mapie nazwa Czerwony Bór nie istniała ${ }^{11}$.

Inną cechą wspólną dla wyżej wymienionych epok są nastroje społeczne, tzn. można powiedzieć, że czas „Solidarności” także odwoływał się do światopoglądu romantyków.

\subsection{ANTECEDENCJE}

Represjonowanie niewygodnych obywateli PRL przez ich pobór do wojska było formą równie starą jak sam PRL. W latach 1949-1956 ok. 10 tys. poborowych z całego kraju zostało powołanych do odbycia „zastępczej służby wojskowej”, która polegała na przymusowej pracy w śląskich kopalniach węgla. Żołnierze górnicy, pochodzący głównie z rodzin tzw. wrogów klasy robotniczej, mieli zastąpić uwolnionych w 1949 r. jeńców niemieckich. ${ }^{12}$ Środkiem represji było przez wiele lat powoływanie do wojska przyszłych księży katolickich. Proces ten trwał,

10 Branka '82, „Hutnik” 1982, nr 32 (31 X), s. 2.

11 Wypowiedź Leszka Jaranowskiego z audycji emitowanej w Radiu Kraków w dniu 16 XII 2007.

12 M. Dąbrowski, Obozy Wojskowe 1982-1983 [referat wygłoszony w dniu 12 IX 2009 w Łodzi podczas konferencji popularno-naukowej „Niepokorni w Kamasze - kartki z kalendarza”], s. 1-2, 
z różnym nasileniem, od 1959 do kwietnia 1980 r. (ostatni pobór w 1979 r.). Był to jeden $z$ elementów gry komunistów wobec Kościoła, w której chodziło m.in. o przejęcie kontroli nad seminariami oraz wymuszanie na poszczególnych biskupach uleglejszej postawy wobec władz. Od 1964 r. funkcjonowały osobne pododdziały dla kleryków w jednostkach wojskowych w Bartoszycach, Brzegu i Szczecinie-Podjuchach. W latach 1959-1980 powołano do wojska 2872 alumnów, z których 130 zrezygnowało z dalszej drogi kapłańskiej ${ }^{13}$. Pomimo wielu prób i zmian w sposobie szkolenia władzom nie udało się osiągnąć swoich celów. Początkowe założenie, aby zachęcić możliwie największą liczbę kleryków do rezygnacji z powrotu do seminarium, szybko okazało się chybione. Władze nie mogły jednak przyznać się do błędu i postanowiły poprzestać na kształtowaniu w alumnach „właściwych” postaw społecznych, co jednak również okazało się trudne. W notatkach służbowych dotyczących postawy księży, którzy przeszli przez służbę wojskową, znajdujemy tylko informację, że większość z nich działała później społecznie i prowadziła wzmożoną pracę duszpasterską. Umiejętności organizatorskie księży przypisywano szkoleniu wojskowemu. Większości alumnów i późniejszych księży służba wojskowa nie tylko nie przyniosła szkody, ale podbudowała i umocniła ich wiarę ${ }^{14}$.

W marcu 1968 r., po zdławieniu manifestacji studenckich, powołano do wojska kilkuset wyrzuconych z uczelni studentów. Ich dokładna liczba jest wciąż nieoszacowana. Zarządzenie z 16 marca 1968 r. ministra obrony narodowej gen. Wojciecha Jaruzelskiego nakazywało utworzenie w ciągu paru dni trzech nieetatowych batalionów wojskowego szkolenia poborowych: w Żaganiu, Hrubieszowie i Braniewie. Uzupełniało je zarządzenie wydane 17 marca „w sprawie powoływania i przebiegu służby wojskowej studentów relegowanych i zawieszonych w prawach studenta". Studentów takich miano powoływać na dwa lata, kierując ich do jednostek w odległych miejscowościach, aby ich rozproszyćc ${ }^{15}$.

Z uzyskanej relacji Wiesława Godlewskiego (działacza „S” z Lubelszczyzny) wynika, że odbywając w latach 1968-1970 służbę wojskową w Jarosławiu, był świadkiem utworzenia osobnego plutonu z około 50 młodych warszawiaków, zatrzymanych podczas ulicznych demonstracji ${ }^{16}$.

[on-line:] http://www.darpoint.pl/pages/Biezace/Niepokornych\%20w\%20kamasze/Referaty/Mar cin\%20Dabrowski\%20-\%20OBOZY\%20WOJSKOWE\%201982-1983.doc (23 VI 2016).

13 Ibidem.

14 K. Cie mięg a, Alumni w Wojsku Polskim w latach 1959-1980 w świetle dokumentów Głównego Zarządu Politycznego Wojska Polskiego, „Biuletyn Wojskowej Służby Archiwalnej” 2006, nr 28, s. 266.

15 M. Dąbrowski, Obozy wojskowe..., s. 1-2.

16 Ibidem. 
Pomysł powoływania do wojska jako elementu rozprawy z „Solidarnością” istniał $\mathrm{w}$ głowach dowództwa Ludowego Wojska Polskiego od początku powstania ruchu. Jak ujawnił płk Ryszard Kukliński w swojej Wojnie z narodem, już w drugiej połowie listopada 1980 r. na posiedzeniu Komitetu Obrony Kraju Ministerstwo Obrony Narodowej proponowało wykorzystanie postanowień o powszechnym obowiązku obrony i m.in. powołanie około 250 tys. rezerwistów, skierowanie studentów do czynnej służby wojskowej, zmilitaryzowanie dużej liczby przedsiębiorstw oraz powołanie około miliona osób do służby w jednostkach Obrony Cywilnej ${ }^{17}$.

Do wprowadzenia stanu wojennego władze przygotowywały się niezwykle skrupulatnie. Tworzono listy osób przeznaczonych do internowania, z których najstarsza pochodzi z 28 października 1980 r., czyli powstała ponad rok przed ogłoszeniem stanu wojennego.

\subsection{INTERNOWANIA A POBÓR DO WOJSKA}

Władze PRL w drugiej połowie 1982 r. zaczęły odchodzić od praktyki internowań, ponieważ nie udała się pełna izolacja uwięzionych. Poza tym planowano zakończyć stan wojenny, a więc równocześnie zrezygnować z procedury internowania. Do takich planów skłaniały nastroje panujące w społeczeństwie oraz opinia międzynarodowa. Łamiąc prawo, wymyślono nowy sposób, do którego zalet należały prostota i skuteczność - pobór rezerwistów do wojska. Jest to metoda mniej widoczna, zarówno dla społeczeństwa, jak i opinii międzynarodowej, ponieważ „do żołnierzy nie przyjedzie biskup ani Czerwony Krzyż” ${ }^{18}$. Wszystko to dotyczy wewnętrznych spraw suwerennego państwa.

Akcję masowego umieszczenia w jednostkach wojskowych działaczy opozycji oraz członków byłego NSZZ „Solidarność” uznać należy za szczególny sposób internowania osób uważanych ze względów politycznych za niebezpieczne dla władzy ${ }^{19}$.

Generałowie Jaruzelski i Czesław Kiszczak wiedzieli o wcielaniu przeciwników politycznych do wojska. Mieli świadomość, że formalnie odbywało się to w ramach obowiązku służby wojskowej, a faktycznie było to izolowanie osób, które według organów bezpieczeństwa zagrażały porządkowi publicznemu. Ich zdaniem była to prewencja represyjna, podobna do internowania - w ten sposób władza chciała ustabilizować sytuację wewnętrzną i uniemożliwić strajki,

17 Ibidem.

18 „Toruński Informator Solidarności” 1982, nr 41 (21 XII), s. 2.

19 P. Litka, Stużba $w$ armii jak internowanie, „Rzeczpospolita” 2012, 5 VI, http://www.rp.pl/artykul/10,887004-Sluzba-w-armii-jak-internowanie.html (2 III 2015). 
pacyfikując opozycję. Na podstawie zestawienia wykonanego w Sztabie Generalnym Wojska Polskiego wiemy, że planowano powołać 4752 działaczy opozycji z 597 zakładów pracy ${ }^{20}$.

Zgodnie $\mathrm{z}$ „Zarządzeniem organizacyjnym dotyczącym dodatkowego sformowania pododdziałów szkoleniowych przekazanym szefom sztabu okręgów wojskowych w dniu 21.10.1982 r. przez Zastępcę Szefa Sztabu Generalnego Wojska Polskiego gen. dyw. Antoniego Jasińskiego" powodem masowego poboru do wojska była ta sama przyczyna co w przypadku zwykłych internowań, tzn. pilna potrzeba odizolowania w dużych zakładach pracy osób podejrzanych o działalność o charakterze wywrotowym, co miało ograniczyć prawdopodobieństwo strajku generalnego ${ }^{21}$.

$\mathrm{Na}$ różnicę pomiędzy zwykłym ośrodkiem internowania a obozem wojskowym zwraca uwagę Adam Siatka: „Miałem skalę porównawczą, jak było w normalnym ośrodku internowania, a jak było w tym wojskowym. Normalny ośrodek internowania w porównaniu z tamtym to jest przedszkole. Tam była gehenna”22.

\subsection{GENEZA WOJSKOWYCH OBOZÓW SPECJALNYCH}

Wojskowe obozy funkcjonowały od listopada 1982 r. do początku lutego 1983 r., a ich geneza związana jest $\mathrm{z}$ wydarzeniami z lata 1982 r. Pomimo trwających represji kilka miesięcy po wprowadzeniu stanu wojennego wiele wskazywało na to, że „Solidarność", która podjęła swoją działalność w podziemiu, daleka jest od rozbicia $^{23}$. Manifestacje 31 sierpnia 1982 r., do których doszło w 66 miejscowościach i w wyniku których straciło życie 8 osób, a ponad 5000 obywateli zostało zatrzymanych, pokazały wciąż realną siłę solidarnościowego podziemia ${ }^{24}$.

8 października 1982 r. Sejm PRL uchwalił nową ustawę o związkach zawodowych, rozwiązującą wszystkie związki zawodowe istniejące przed 13 grudnia 1981 r., w tym NSZZ „Solidarność” (jej majątek kilka miesięcy później został skonfiskowany). W odpowiedzi Tymczasowa Komisja Koordynacyjna zaapelowała o przeprowadzenie 10 listopada 1982 r. ogólnopolskiego strajku protestacyjnego

$20 \quad$ Ibidem.

21 Archiwum Instytutu Pamięci Narodowej (dalej: AIPN) w Warszawie, BU 1409/32, t. 1, Założenia organizacyjne dotyczace dodatkowego sformowania pododdziałów szkoleniowych przekazane Szefom Sztabu Okręgów Wojskowych w dniu 21 X 1982 r. przez Zastępcę Szefa Sztabu Generalnego Wojska Polskiego gen. Dyw. Antoniego Jasińskiego, k. 1-4, [on-line:] http://www.13grudnia81.pl/portal/ sw/1497/9529 (24 III 2015).

22 Wypowiedź Adama Siatki z audycji emitowanej w Radiu Kraków 16 XII 2007.

23 M. Dąbrowski, Wojskowe obozy..., s. 19.

24 H. Głęb o cki, Dzieje „Solidarności” w podziemiu, [w:] Droga do niepodległości 1980-2005, Warszawa 2005, s. 180. 
w drugą rocznicę zarejestrowania NSZZ „Solidarność”. Do tego czasu miało miejsce kilka strajków na Wybrzeżu oraz parodniowe zamieszki w niektórych ośrodkach w kraju, m.in. w Gdańsku, Wrocławiu i Krakowie-Nowej Hucie.

Zapowiedź podjęcia akcji protestacyjnych 10 listopada 1982 r. władze stanu wojennego potraktowały bardzo poważnie. Najprawdopodobniej wtedy musiał pojawić się pomysł spacyfikowania podziemnej „Solidarności” przez pobór do wojska związkowców mogących stanowić dla władzy potencjalne niebezpieczeństwo ${ }^{25}$.

Pomysł ten był przetestowany w warunkach stanu wojennego na osobach rekrutujących się z marginesu społecznego. Od stycznia do lutego 1982 r. powołano do wojska 6409 osób z przeszłością kryminalną (łącznie do końca 1983 r. 7555 osób) ${ }^{26}$. Tłumaczy to szybkość akcji podjętej przeciw działaczom „Solidarności”.

21 października 1982 r. dyrektor Departamentu V MSW w Warszawie, płk Sasin, wystosował szyfrogram do zastępców komendantów wojewódzkich MO ds. SB „,W sprawie wytypowania osób podejrzanych o organizowanie strajków, zajść ulicznych, czynną wrogą działalność (druk, kolportaż), a nienadających się $\mathrm{z}$ różnych powodów do internowania lub zatrzymania, w celu powołania ich na ćwiczenia wojskowe lub do odbycia zasadniczej służby wojskowej”27. Miały to być osoby rekrutujące się głównie z dużych zakładów, a wiek wytypowanych miał nie przekraczać 28 roku życia. Bezpieczni mogli się czuć tylko jedyni żywiciele rodzin, osoby prowadzące gospodarstwa rolne oraz te $\mathrm{z}$ kategorią zdrowia B (czasowo niezdolni) i D (trwale niezdolni do służby wojskowej).

Powołując się na decyzję kierownictwa MON i MSW, płk Sasin zalecał powołać wytypowane osoby na „ćwiczenia” w dniach 2 i 3 listopada 1982 r. Część jako rezerwiści miała być zgrupowana na trzy miesiące w jednostkach pontonowych i Obrony Terytorialnej Kraju w Chełmnie, Rawiczu i Dęblinie. Poborowi mieli być wcieleni do służby wojskowej na dwa lata ${ }^{28}$. Warto wspomnieć, że większość wytypowanych miała już odbytą służbę wojskową i była rezerwistami w stopniu od szeregowca do starszego kaprala (w jednym przypadku - plutonowego) lub od marynarza do starszego mata, ewentualnie - kanoniera lub bombardiera ${ }^{29}$.

25 M. Dąbrowski, Wojskowe obozy..., s. 20.

26 P. Piotrowski, Kompanie polowe w „ludowym” Wojsku Polskim jako forma represji politycznych. Zarys problemu, „Zeszyty Historyczne WiN-u” 2010, nr 32/33 (Historia i pamięć. Księga dedykowana Januszowi Kurtyce), s. 429-437.

27 M. Dąbrowski, Wojskowe obozy..., s. 21.

28 IPN BU 14/32, t. 1, Zarządzenie Szefa Sztabu Generalnego Wojska Polskiego Nr 0141 Mob. Z dnia 26 X 1982 r. w sprawie powołania określonej grupy poborowych do odbycia zasadniczej służby wojskowej oraz żołnierzy rezerwy na ćwiczenia wojskowe, k. 74-81, [on-line:] http://www.13grudnia81.pl/ portal/sw/1497/9527 (5 IV 2015).

29 M. Dąbrowski, Wojskowe obozy..., s. 31-32. 
W praktyce szeregi rezerwistów miały zasilić również osoby o kategoriach zdrowia B lub nawet D, czyli trwale niezdolne do służby wojskowej.

Dalsze działania prowadzone były dwutorowo, ponieważ równolegle z MSW własne przygotowania podjęło MON. 21 października 1982 r. gen. dyw. Jasiński przeprowadził telekonferencję z Zastępcami Dowódców Okręgów Wojskowych, przekazując szefom Sztabu Okręgów Wojskowych założenia organizacyjne dotyczące dodatkowego sformowania pododdziałów szkoleniowych. Zwracano uwagę na pilną potrzebę „odizolowania”, zwłaszcza w dużych zakładach pracy, osób stanowiących główny trzon grup o charakterze wywrotowym ${ }^{30}$.

Pierwotny zamysł przewidywał powołanie do czynnej służby wojskowej w dniach 3-4 listopada 1982 r. od 500 do 600 osób będących żołnierzami rezerwy celem odbycia trzymiesięcznych ćwiczeń wojskowych i około 1000 poborowych do odbycia dwuletniej zasadniczej służby wojskowej. Parytet powołania poborowych miał być następujący: 300 osób z Warszawskiego Okręgu Wojskowego, 350 osób z Pomorskiego Okręgu Wojskowego i 350 osób ze Śląskiego Okręgu Wojskowego ${ }^{31}$.

Typowaniem planowano objąć duże zakłady pracy w 32 województwach: białostockim, bielskim, bydgoskim, częstochowskim, elbląskim, gdańskim, gorzowskim, kaliskim, katowickim, koszalińskim, krakowskim, krośnieńskim, legnickim, lubelskim, łódzkim, olsztyńskim, opolskim, pilskim, piotrkowskim, płockim, poznańskim, radomskim, rzeszowskim, słupskim, szczecińskim, tarnowskim, toruńskim, wałbrzyskim, warszawskim, włocławskim, wrocławskim i zielonogórskim. W praktyce pobór wykroczył poza planowany teren, obejmując 27 osób z terenu Wojskowej Komendy Uzupełnień w Nisku (ośrodek Stalowa Wola) w województwie tarnobrzeskim, 2 osoby z województwa suwalskiego i 1 osobę z województwa zamojskiego. Wszystkie one trafiły do obozu w Czerwonym Borze ${ }^{32}$.

Z każdego wytypowanego zakładu pracy miała być powołana „grupa osób stanowiąca trzon aktywistów prowokujących zajścia”33. Wyraźnie była mowa o tym, że typowania żołnierzy rezerwy i poborowych do odbycia omawianych form służby wojskowej „dokonują organy WSW wspólnie z organami Służby Bezpieczeństwa" oraz że listy wytypowanych do powołania żołnierzy i poborowych miały przedstawić do WKU właściwe organy MSW za pośrednictwem oficerów

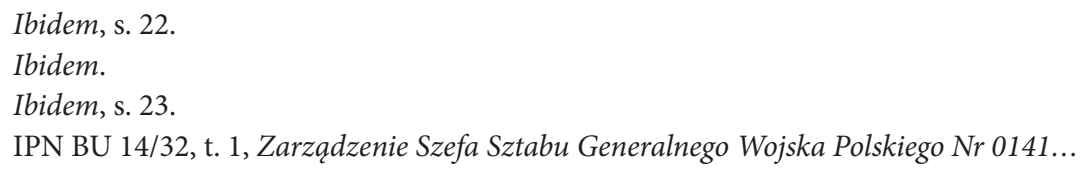


WSW ds. doboru. Dowodzi to, jak bliska była współpraca obu resortów w całym przedsięwzięciu ${ }^{34}$.

Wybrane osoby spośród żołnierzy rezerwy planowano powołać do 9 Pułku Pontonowego w Chełmnie (POW) - ok. 300 żołnierzy, 10 Batalionu Pontonowego w Rawiczu (ŚOW) - od 100 do 150 żołnierzy oraz 7 Pułku Pontonowego w Dęblinie (WOW) - 200 żołnierzy ${ }^{35}$.

Przy typowaniu oddziałów wojskowych, do których poborowi mieli być kierowani na pierwsze dwa miesiące szkolenia podstawowego, zalecano wyłączenie jednostek, w których odbywało się szkolenie podoficerów i młodszych specjalistów, jednostek w dużych aglomeracjach miejskich, w rejonach uprzemysłowionych oraz $\mathrm{w}$ rejonach, gdzie miały miejsce różnego rodzaju akcje protestacyjne. Jako najlepiej nadające się wskazywano tzw. zielone garnizony. Po dwumiesięcznym okresie szkoleniowym poborowych zamierzano rozesłać do jednostek kolejowych i drogowych ${ }^{36}$.

Harmonogram działań przewidywał, że wykazy żołnierzy rezerwy i poborowych zostaną dostarczone do WKU w dniach 22-23 października 1982 r. przez oficerów WSW ds. poboru, zaś 28-30 października 1982 r. doręczone miały być karty powołania ze stawiennictwem w jednostkach wyznaczonym na 3-4 listopada 1982 r. $^{37}$

Ostatnim z zarządzeń na najwyższym szczeblu wojskowym było „Zarządzenie Sztabu Generalnego Wojska Polskiego nr 0141 z 26 października 1982 r.” Jego następstwem była prowadzona 27-29 października 1982 r. akcja wzywania do Wojskowych Komend Uzupełnień lub bezpośrednie doręczanie kart mobilizacyjnych. Zarządzenie precyzowało powołanie w dniach 5-6 listopada 1982 r. grupy 1370 podoficerów i szeregowych rezerwy z dodaniem do tej liczby maksymalnie 15 procent nadwyżki „na zabezpieczenie stawiennictwa i na ewentualne wykruszenia”. Z Pomorskiego Okręgu Wojskowego miało pochodzić 560 rezerwistów, 420 z Warszawskiego Okręgu Wojskowego i 390 ze Śląskiego Okręgu Wojskowego. Pobór miał także objąć 355 osób do odbycia dwuletniej zasadniczej służby wojskowej (140 poborowych z Pomorskiego OW, 115 z Warszawskiego OW i 100 poborowych ze Śląskiego OW).

Rozkaz precyzował rozdział rezerwistów z poszczególnych okręgów wojskowych do konkretnych jednostek wojskowych. Z Pomorskiego Okręgu Wojskowe-

\footnotetext{
M. D ąbrowski, Wojskowe obozy..., s. 23.

Ibidem.

Ibidem, s.24.

37 IPN BU 0236/263, t. 1, Szyfrogram dyrektora Departamentu V MSW Józefa Sasina do zastępców komendantów wojewódzkich MO ds. Służby Bezpieczeństwa z dnia 21 października 1982 r., k. 296-297, [on-line:] http://www.13grudnia81.pl/portal/sw/1497/9528 (24 III 2015).
} 
wego: 300 podoficerów i szeregowych rezerwy miało trafić do 9 Pułku Pontonowego w Chełmnie nad Wisłą, 150 podoficerów i szeregowych rezerwy kierowano do 19 Batalionu Saperów w Unieściu, zaś 110 szeregowych rezerwy wysyłano do 2 Batalionu Inżynieryjnego Wojsk Obrony Wewnętrznej w Czerwonym Borze (Jednostka Wojskowa nr 3466).

Ze Śląskiego Okręgu Wojskowego 150 żołnierzy rezerwy kierowano do $10 \mathrm{Ba}-$ talionu Pontonowego w Rawiczu. Po 80 podoficerów i szeregowych rezerwy wysyłano do trzech jednostek: 1 Brygady Saperów w Brzegu, 4 Brygady Saperów w Gorzowie Wielkopolskim i 6 Pułku Pontonowego w Głogowie.

Z terenu Warszawskiego Okręgu Wojskowego 270 podoficerów i szeregowych rezerwy kierowano do 2 Batalionu Inżynieryjnego Wojsk Obrony Wewnętrznej w Czerwonym Borze, 75 podoficerów i szeregowych rezerwy - do 28 Pułku Czołgów w Czarnem koło Szczecinka (Jednostka Wojskowa nr 2198), 75 podoficerów i szeregowych rezerwy - do 68 Pułku Czołgów Średnich w Budowie koło Złocieńca (Jednostka Wojskowa nr 1013) (Rys. 1.).

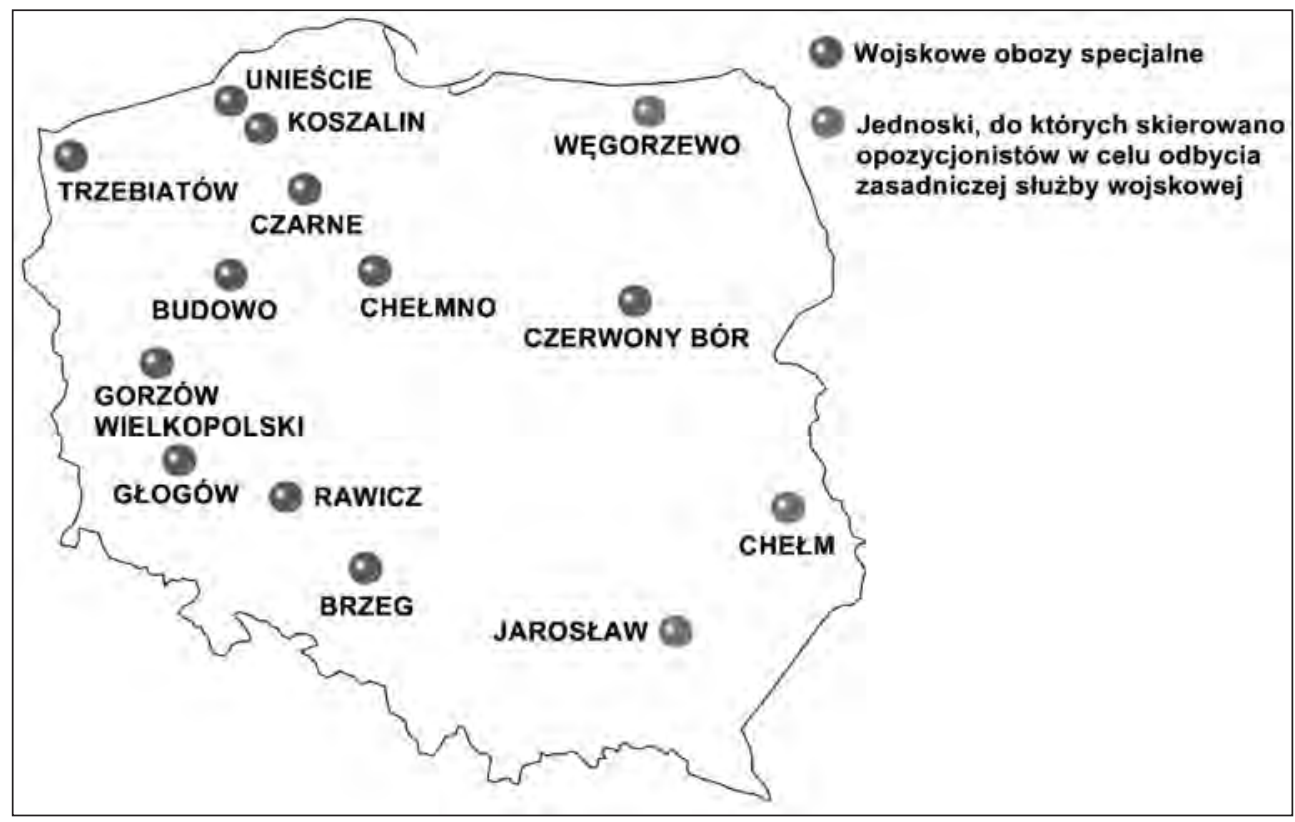

Rys. 1. Mapa przedstawiająca rozmieszczenie jednostek wojskowych, do których skierowano opozycjonistów (opracowanie własne)

Wszystkich poborowych (355 osób) kierowano na teren Warszawskiego Okręgu Wojskowego. Klucz ich rozdziału w ramach WOW był następujący: 140 poborowych z Pomorskiego OW - do 1 Brygady Artylerii Armat w Węgorzewie 
(Jednostka Wojskowa nr 2568), 115 poborowych z Warszawskiego OW - do 5 Pułku Artylerii w Chełmie (Jednostka Wojskowa nr 1991), 100 poborowych ze Śląskiego OW - do 40 Pułku Artylerii w Jarosławiu (Jednostka Wojskowa nr 2376). Na poborowych czekała szczególna „niespodzianka”. Po okresie szkolenia podstawowego szeregowi mieli być skierowani do jednostek kolejowych oraz drogowych i zatrudnieni przy pracach budowlanych i remontowych ${ }^{38}$.

Z 29 października 1982 r. pochodzi „Wykaz osób wytypowanych przez pion Departamentu III do odbycia zasadniczej służby wojskowej lub ćwiczeń wojskowych” zawierający 384 nazwiska z 32 województw. Najwięcej, 64 nazwiska z Gdańska (w tym Donald Tusk i Lech Kaczyński), 43 z Łodzi, 40 z Wrocławia i 35 z Poznania. Wiele z tych osób ostatecznie nie trafiło do obozów. Na liście z Warszawy figuruje m.in. ukrywający się wówczas Zbigniew Bujak. Wiadomo było też, że Wydział III Komendy Stołecznej zgłosił do odbycia zasadniczej służby tajnego współpracownika o pseudonimie „Karol” ${ }^{39}$. Tego typu działania miały prowadzić do inwigilacji związkowców powołanych do wojska.

Z telegramu zastępcy szefa sztabu Pomorskiego Okręgu Wojskowego ds. organizacyjno-mobilizacyjnych płk. dypl. Jana Popiela z 27 października 1982 r. wynikało, że w sposób szczególny pobór rezerwistów dotknął wytypowane zakłady pracy. Na terenie Pomorskiego OW były to zwłaszcza: Gdańska Stocznia Remontowa (21 osób), Zakłady Mechaniczne „Zamech” w Elblągu (20 osób), Zakłady Petrochemiczne „Płock” (15 osób), Olsztyńskie Zakłady Opon Samochodowych „Stomil” (13 osób) i Stocznia im. Warskiego w Szczecinie (10 osób) ${ }^{40}$.

O tym, w jak dużym stopniu władze obawiały się wówczas tego, co może nastąpić 10 i 11 listopada 1982 r. w kraju, świadczy obszerny „Plan działań Departamentu III MSW na okres od 2 do 13 listopada 1982 r.", a także delegowanie pracowników Departamentu III do „najbardziej zagrożonych” Komend Wojewódzkich MO w kraju ${ }^{41}$.

Śladów tych obaw, jak również przygotowań do poboru, należałoby szukać w sprawach obiektowych prowadzonych przez Służbę Bezpieczeństwa przeciw poszczególnym regionom „Solidarności”. Na przykład w aktach Sprawy Obiektowej o kryptonimie „Związek”, nakierowanej na działalność Zarządu Regionu

38 IPN BU 14/32, Zarządzenie Szefa Sztabu Generalnego Wojska Polskiego Nr 0141...

39 IPN BU 0236/263, Wykaz osób wytypowanych przez pion Departamentu III do odbycia zasadniczej stużby wojskowej lub ćwiczeń wojskowych w b.r., k. 362-382.

40 IPN BU 1409/30, Telegram Zastępcy Szefa Sztabu Pomorskiego Okręu Wojskowego ds. organizacyjno -mobilizacyjnych płk dypl. Jana Popiela, 27 X 1982 r., k. 136-143, [on-line:] http://www.13grudnia81. $\mathrm{pl} /$ portal/sw/1497/9531 (5 IV 2015).

41 IPN BU 0236/263, t. 1, Plan działań Departamentu III MSW na okres od 2 do 13 listopada 1982 r., k. 382-384. 
Środkowo-Wschodniego, sporządzono „Plan przygotowań operacyjno-zapobiegawczych" przewidzianych na okres 6-14 listopada 1982 r., zmierzających do „zneutralizowania inicjatyw podejmowanych przez osoby i grupy zaangażowane w działalność w nielegalnych strukturach «S»". Przewidywał on m.in. wytypowanie osób o postawach ekstremalnych, przewidzianych do internowania, powołania do czynnej służby wojskowej oraz do zatrzymań prewencyjnych. Celem zmniejszenia zagrożenia w związku z planowanym przez podziemie „Solidarności” strajkiem powszechnym zamierzano w Lublinie powołać do czynnej służby wojskowej 18 osób „rozpoznanych jako agitatorów i inicjatorów zakłócenia porządku publicznego”42.

Również w rejonie środkowo-wschodnim władze proponują chłoporobotnikom stawiającym się do poboru w swoich zakładach pracy zamiast służby dwuletnią pracę w Świdniku. Zastrzegając przy tym, że jeśli wdadzą się w jakąś akcję protestacyjną czy inną działalność, natychmiast zostaną wysłani do wojska, a odpracowany przez nich czas przepadnie. W ten sposób władze chciały uzyskać całkowitą uległość grupy skierowanej do Świdnika. Opozycjoniści apelowali w prasie podziemnej, że zgoda na pobyt w Świdniku jest całkowitym poddaniem się władzy ${ }^{43}$.

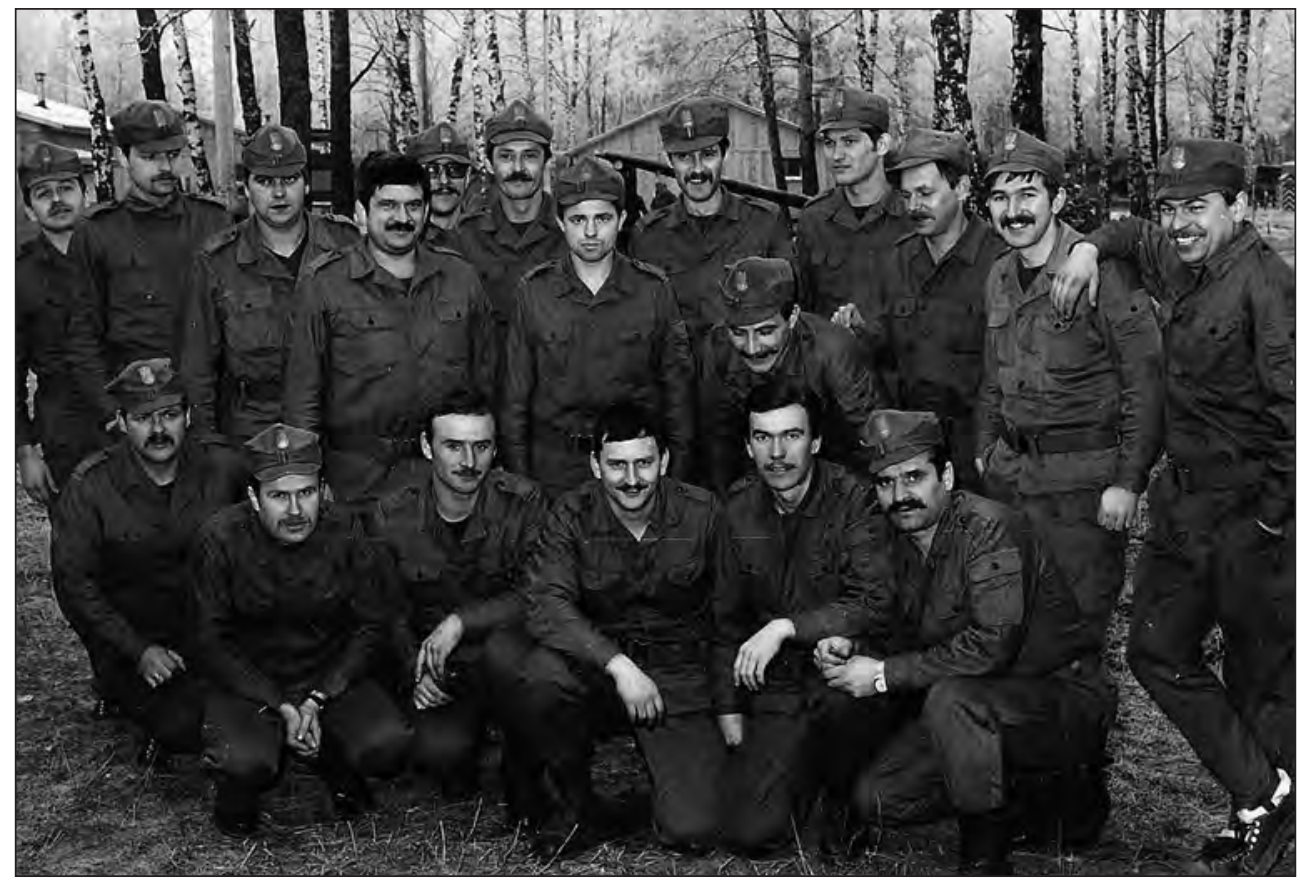

Internowani poborowi z obozu w Czerwonym Borze - jesień 1982

42 M. Dąbrowski, Wojskowe obozy..., s. 28.

43 „Informator” (Lublin) 1982, nr 42 (3 XI). 
Z kolei w aktach Wydziału II SB KW MO w Lublinie (kontrwywiad) w „Informacji” ${ }^{44}$ z 1 grudnia 1982 r. wspomniano o wcieleniu około 15 osób do odbycia służby wojskowej. Wynika $\mathrm{z}$ tego, że typowanie list kandydatów do obozów prowadzono $\mathrm{z}$ udziałem różnych pionów $\mathrm{SB}$.

Echa pobytu w obozach wojskowych mogą się także znajdować w zachowanych teczkach SB dotyczących poszczególnych osób objętych poborem. Przykładem takim mogą być akta inwigilacji Andrzeja Kwaśnego (kryptonim „Kolporter”, „Uparty”) ze Stargardu Szczecińskiego, powołanego do Czerwonego Boru ${ }^{45}$.

Podczas spotkania inspektora śledczego prowadzącego sprawę Kwaśnego z TW o pseudonimie „Ryś” w sprawie miejsc oraz osób mających związek z wytwarzaniem biuletynu „Jedność” w Stargardzie Szczecińskim TW zwrócił uwagę na osoby, które przebywały z Kwaśnym w Czerwonym Borze. Świadczyć to może o pozytywnym wpływie internowania, tzn. zawieraniu wartościowych znajomości. Wedle spekulacji służb mogły tam być też omawiane sposoby kontaktowania się i przekazywania wiadomości w prasie podziemnej ${ }^{46}$.

\section{REPRESJE POLITYCZNE POPRZEZ POWOLYWANIE} DO FORMACJI WOJSKOWYCH W LATACH 1981-1983

Od 5 listopada 1982 do 3 lutego 1983 r. 1447 osób zostało powołanych na trzymiesięczne szkolenie wojskowe $\mathrm{w}$ ramach służby czynnej ${ }^{47}$. W zdecydowanej większości osoby te były tzw. drugim garniturem „Solidarności”, czyli członkami Komisji Zakładowych i działaczami szczebla zakładowego NSZZ „\$” oraz współorganizatorami strajków i protestów z 13 grudnia. W znacznym stopniu osoby te były w wieku średnim (głównie roczniki 1940-1962), w mniejszości były osoby urodzone przed $1940 \mathrm{r}$.

Dla rezerwistów powołanych na trzymiesięczne „ćwiczenia” utworzono 10 kompanii polowych rezerwy zlokalizowanych w pobliżu jednostek wojskowych w Brzegu, Budowie, Chełmie nad Wisłą, Czarnem, Czerwonym Borze, Głogowie, Gorzowie Wielkopolskim, Rawiczu, Trzebiatowie i Unieściu/Koszalinie ${ }^{48}$.

$44 \quad$ M. Dą browski, Wojskowe obozy..., s. 28.

45 IPN Sz 0053/96, Sprawa Operacyjnego Sprawdzenia [SOS] o krypt. „Kolporter”/ „Uparty”, s. 15.

46 Ibidem, s. 41.

47 M. D ąb rowski, Wojskowe obozy..., s. 31. Wykaz internowanych działaczy zestawiony wg obozów zob.: Żotnierze rezerwy powołani na trzymiesięczne przeszkolenie wojskowe w ramach służby czynnej, oprac. Ł. Rabczyński, [w:] Inteligentna forma internowania, aneks, s. 323-428.

48 Ibidem, s. 32. 


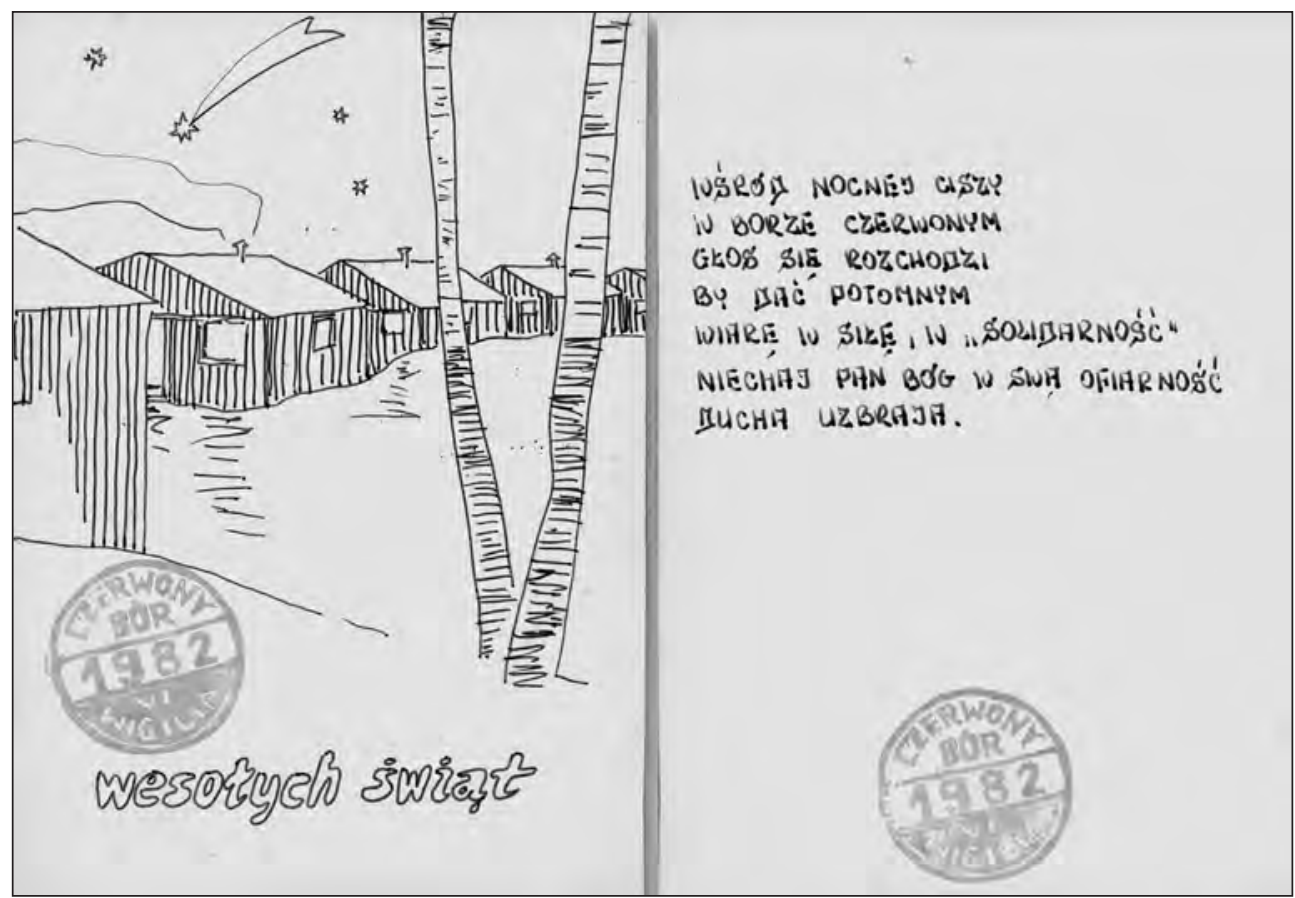

Kartka świąteczna z obozu w Czerwonym Borze - Wigilia 1982

„Obozy" dla rezerwistów położone były głównie w północnej i zachodniej Polsce. Na Dolnym Śląsku Brzeg (JW 2697) oraz Głogów (JW 1527), na Pomorzu Zachodnim Budowo koło Złocieńca (JW 1013), na Kujawach Chełmno nad Wisłą (JW 1636), Czarne koło Szczecinka (JW 2198), na północno-wschodnim Mazowszu był to Czerwony Bór koło Zambrowa (JW 3466), na ziemi lubuskiej Gorzów Wielkopolski (JW 1649), w południowej Wielkopolsce Rawicz (JW 2697), na Pobrzeżu Szczecińskim Trzebiatów (JW 3126) i na środkowym Wybrzeżu Unieście/Koszalin (JW 5691) ${ }^{49}$.

\subsection{BRZEG}

Obóz zlokalizowany był na terenie Jednostki Wojskowej nr 2697 w Brzegu (1 Brygada Saperów). Nie był to największy ośrodek pod względem liczebności, przebywało tu 87 osób rekrutujących się głównie z ówczesnych województw: wrocławskiego, legnickiego, gorzowskiego i częstochowskiego. Wśród rezerwistów znajdowało się też kilka osób skierowanych do wojska bezpośrednio z Ośrodka Odosobnienia w $\mathrm{Nysie}^{50}$.

49 Ibidem.

$50 \quad$ Ibidem, s. 37. 
Rezerwiści zostali zgrupowani w jedną kompanię, zakwaterowaną na osobnym piętrze w jednym z budynków koszar. Aby oddzielić rezerwistów od żołnierzy, rozesłano informacje, że są to osoby bezrobotne o przeszłości kryminalnej. Za wiarygodnością takich stwierdzeń przemawiał fakt istnienia w tym czasie zbliżonych formacji rekrutujących osoby wywodzące się ze środowisk przestępczych ${ }^{51}$.

Do codziennych zajęć żołnierzy rezerwy należały prace fizyczne niemające nic wspólnego $\mathrm{z}$ podnoszeniem umiejętności wojskowych. W Brzegu były to m.in. prace ziemne, takie jak kopanie rowów na jednym $z$ dwóch poligonów Żłobizny koło lotniska sowieckiego Pępice lub Pawłów nad Odrą. Do pracy zmuszano wszystkich, także osoby mające stopień kaprala, co było w wojsku niedopuszczalne. Ze względu na upokarzające traktowanie rezerwiści szybko przestali nosić dystynkcje. O niesprawiedliwym traktowaniu żołnierzy rezerwy świadczyć może to, że dowódcami drużyn byli żołnierze służby zasadniczej, z reguły mający niższe stopnie niż niektórzy $\mathrm{z}$ rezerwy.

Przykładem jednego z konfliktów rezerwistów i kadry wojskowej była wizyta prokuratora, podczas której wypowiedział się on na temat rygorów panujących w czasie stanu wojennego. Podczas przemówienia prokuratora jeden z żołnierzy rezerwy przypiął na zewnętrznej stronie drzwi do sali kartkę z karykaturą Jaruzelskiego, ukazanego jako kukiełka sterowana z góry sznurkami za pomocą sierpa i młota. WSW ustaliło w wyniku dochodzenia, że autorem rysunku był rezerwista z Gorzowa Wielkopolskiego (nazwiska nie udało mi się ustalić) ${ }^{52}$. Został on wywieziony z jednostki i aresztowany, a później prawdopodobnie skazany w procesie sądowym.

Do konfliktów dochodziło również na tle religijnym. Jednym z nich był zatarg z dowódcą brygady, gdy dwaj reprezentanci rezerwistów zwrócili się w imieniu całej grupy o możliwość uczestnictwa w niedzielnych mszach świętych. Gdy jeden z przedstawicieli rezerwistów usłyszał: „Stul pysk!”, rozmowa została zakończona. Aby nie pozostać dłużnymi, rezerwiści podczas apelu na pozdrowienie: „Czołem, kompania rezerwy!”, odpowiedzieli jednogłośnie: „Stul pysk!”53.

W obrębie rezerwy dość szybko wyłoniono „dowództwo”, które decydowało w sprawie działań i zachowań kompanii. Ze względu na obecność agentów struktura miała tajny charakter. W skład „dowództwa” wchodzili m.in.: Józef Adamski, Tadeusz Jaremko, Bogdan Jetz i Marek Żudrak.

W kompanii znajdowali się też współpracownicy WSW. Byli oni szybko wykrywani, ze względu na nieuczestniczenie w pracach fizycznych na poligonach.

51 P. Piotrowski, Stużba wojskowa jako forma represji..., s. 47.

52 M. Dąbrowski, Wojskowe obozy..., s. 37.

53 Ibidem, s. 37-38. 
Mieli oni wypracowany system kontaktowania się ze swoimi przełożonymi. Polegał on na częstych wyjściach do lekarza, podczas których tak naprawdę kierowali się do zakamuflowanego piętro wyżej w tym samym budynku gabinetu oficera kontrwywiadu. Jeden TW rozpoznany wśród rezerwistów nosił pseudonim „Do-

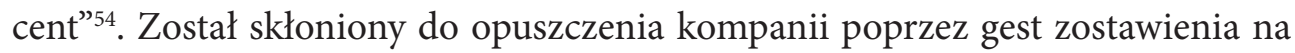
jego łóżku pętli sznura z tekstem ostrzegawczym. Kolejnym donosicielem okazał się zainstalowany w kompanii podkarpacki kłusownik, który miał w ten sposób odkupić swoje przestępstwa ${ }^{55}$.

Normą była ciągła indoktrynacja polityczna, obowiązkiem było oglądanie „Dziennika Telewizyjnego”. Tablice informacyjne obfitowały w plakaty propagandowe oczerniające „Solidarność". Ze względu na notorycznie pojawiające się na plakatach napisy „KPN” zrezygnowano z tej metody indoktrynacji.

Do ulubionych aktywności rezerwistów należało organizowanie wykładów we własnym gronie oraz śpiewanie podczas przemarszów piosenek typu „Ronald Regan naszym przyjacielem jest”. Śpiewem „uczczona” została również śmierć Leonida Breżniewa. Tadeusz Jaremka z Legnicy tworzył satyryczne rysunki, które były urozmaiceniem dla rezerwistów, ponieważ ośmieszały rzeczywistość życia w jednostce ${ }^{56}$.

Pomieszczenia zamieszkiwane przez rezerwistów przez cały okres służby były poddawane rewizji. W trakcie najbardziej gruntownej z nich zarekwirowano wiele przedmiotów, na co odpowiedzią była trzydniowa głodówka protestacyjna. Najprawdopodobniej w związku z tymi wydarzeniami jednostkę wizytował prokurator z Katowic z ostrzegawczym wykładem. Raz na miesiąc (najprawdopodobniej 16. dnia) podczas obiadu rezerwiści minutą ciszy czcili ofiary stanu wojennego.

W drugiej połowie grudnia 1982 r. kompania rezerwistów została przeniesiona na teren poligonu w Pępicach. Zakwaterowani zostali w namiotach ogrzewanych za pomocą piecyków, tzw. kóz. Tam kontynuowano dotychczasowe roboty ziemne. Żołnierze rezerwy mieli podczas całego pobytu tylko jeden kontakt $\mathrm{z}$ bronią, gdy urządzono im próbne strzelanie ${ }^{57}$.

\subsection{Budowo}

Obóz zlokalizowany był na terenie JW nr 1013 o nazwie Budowo (obecnie Budów) w województwie koszalińskim na Pomorzu Zachodnim, w pobliżu miasteczka Złocieniec. Kompleks budowli wzniesiony został przez Niemców w 1936 r.

\footnotetext{
$54 \quad$ Ibidem, s. 39.

55 Ibidem.

56 Ibidem, s. 38.

57 Ibidem, s. 39.
} 
i stanowił wówczas ośrodek szkoleniowy młodej kadry partyjnej NSDAP. Była to tak zwana Twierdza Zakonna nad jeziorem Krosino (Ordensburg am Krossinsee $)^{58}$. Skierowano tu 77 osób pochodzących z województw: warszawskiego, radomskiego, piotrkowskiego, lubelskiego, kieleckiego i białostockiego. Powstała z nich „kampania saperów rezerwy” w ramach 68 Pułku Czołgów Średnich ${ }^{59}$.

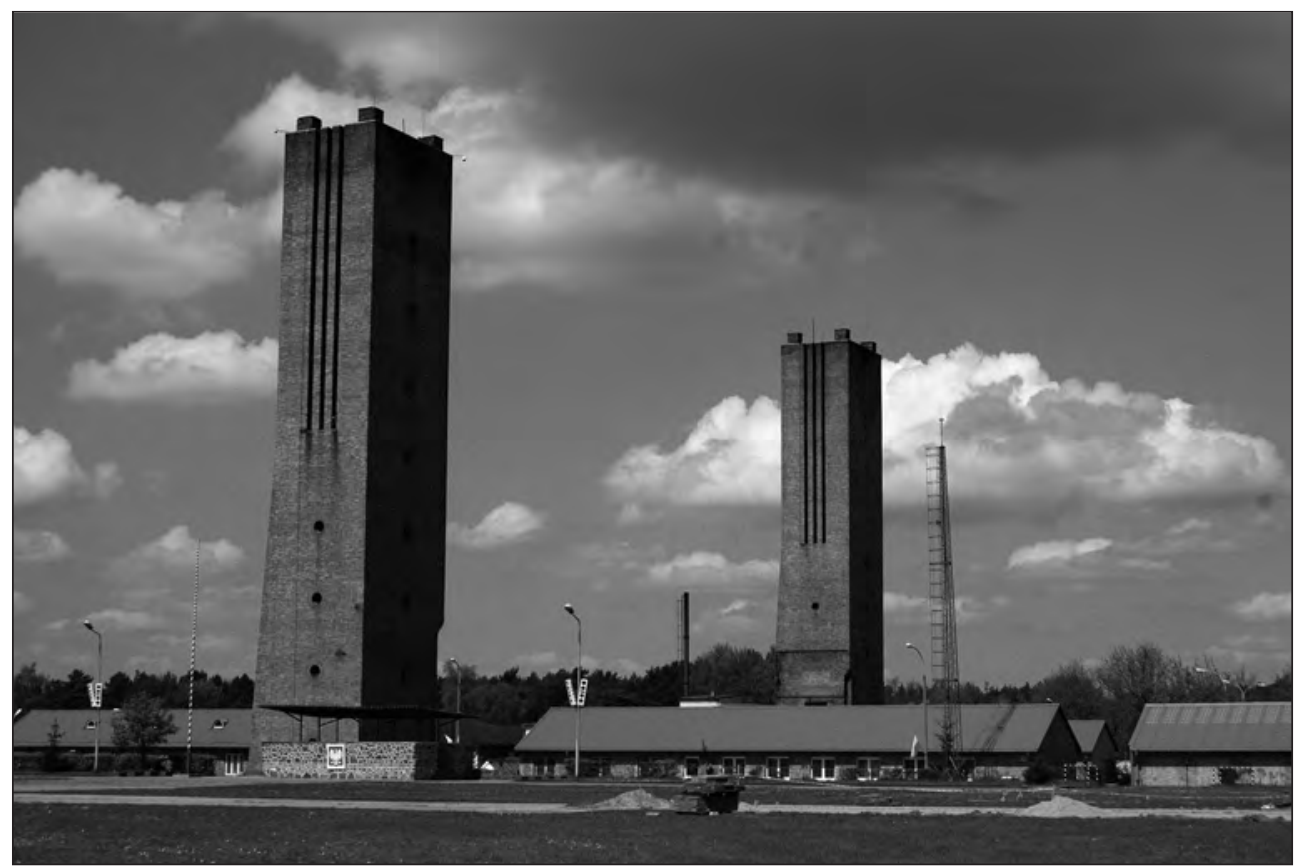

Poniemieckie zabudowania w obozie internowanych „żołnierzy” w Budowie

Rezerwiści byli ulokowani w trzech drewnianych barakach znajdujących się poza właściwymi koszarami (okolice Drawy) i odizolowanych od jednostki. Izolację pogłębiał fakt, że osoby mieszkające na osiedlach wojkkowych zostały ostrzeżone o przybyciu niebezpiecznych degeneratów i narkomanów ${ }^{60}$. W rozmowach prowadzonych po latach z żołnierzami zawodowymi stacjonującymi w Budowie zaprzeczają oni, jakoby w ich jednostce znajdowała się kompania złożona $\mathrm{z}$ „solidarnościowców", wspominają tylko o kompanii polowej, w której według ich wiedzy służyli kryminaliści ${ }^{61}$. Jeden z żołnierzy rezerwy (Zbigniew Gruca) już pierwszego dnia został ukarany jednodniowym aresztem za odmowę założenia

58 „Budowo”, ze strony http://www.darpoint.pl/BUDOWO/wos_Budowo.htm (6 I 2016).

59 M. Dąbrowski, Wojskowe obozy..., s. 39.

60 R. Sawinski, J. Leszczełowki, Od nazistowskiej twierdzy do polskich koszar. Historia obiektu w Budowie koło Złocieńca, Warszawa 2008, s.166.

$61 \quad$ Ibidem, s.162. 


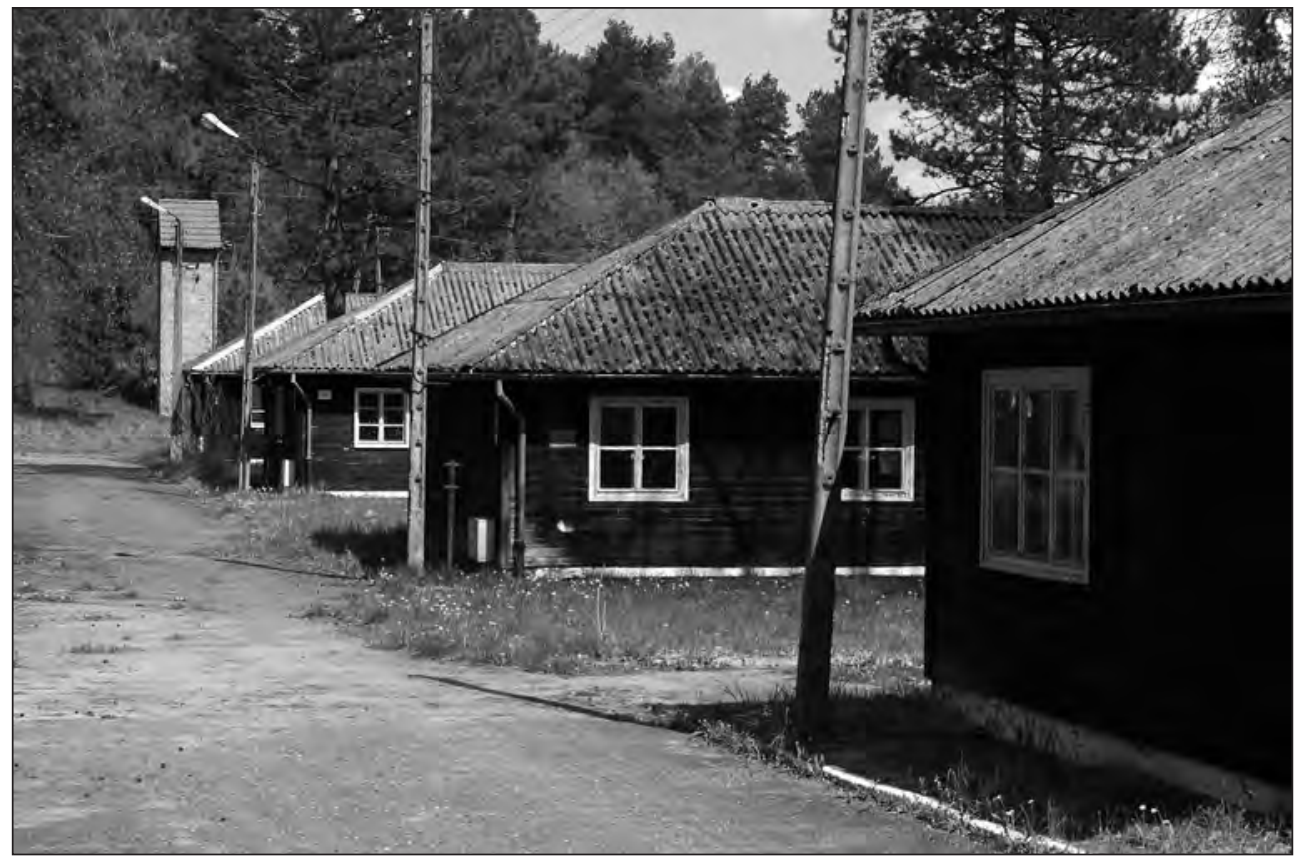

Baraki mieszkalne internowanych „żołnierzy” w obozie w Budowie

munduru i poddania się rozkazom. Usprawiedliwiał się zaświadczeniem lekarskim o niezdolności do odbywania służby wojskowej ${ }^{62}$.

Podobnie jak w pozostałych obozach żołnierze rezerwy angażowani byli do zajęć niemających wiele wspólnego ze służbą wojskową, tzn. do prac ziemnych na poligonie Drawsko Pomorskie. Prace te związane były z wyrównywaniem kolein po czołgach, kopaniem i zasypywaniem dołów oraz naprawą strzelnicy wojskowej. Pod koniec służby rezerwistom zlecano łagodniejsze roboty, np. zamiatanie dróg na osiedlu wojskowym. Dzień był zorganizowany w ten sposób, aby poszczególne plutony nie kontaktowały się wzajemnie (spotykano się dopiero w kwaterach).

Nie było możliwości odwiedzin ze strony rodziny i bliskich przez cały okres powołania. Przepustki nie były wydawane (udzielano ich z nieznanych powodów 2-3 osobom $)^{63}$. Korespondencja przychodząca nie była przekazywana. Pozwalano jedynie na wysyłanie kartek i listów.

$\mathrm{Na}$ początku służby władze jednostki organizowały zajęcia ideologiczne z udziałem oficerów politycznych (np. kpt. Kapturkiewicz). Zaprzestano ich ze względu na porażki odnoszone przez owych oficerów w dyskusjach z rezerwistami.

62 M. Dąbrowski, Wojskowe obozy..., s. 40.

63 Ibidem. 
Zaniechano również musztry, która przybierała czasem groteskowy charakter (maszerowano dwa kroki do przodu, jeden w tył) ${ }^{64}$. Obowiązkowe było oglądanie wieczornego „Dziennika Telewizyjnego” (z entuzjazmem zareagowano na informację o śmierci Leonida Breżniewa).

W jednostce było fatalne wyżywienie. O jakości wyżywienia świadczyć może np. to, że zaraz po zjedzeniu pierwszej kolacji w obozie Stanisław Czopowicz wylądował na izbie chorych ${ }^{65}$. 10-11 listopada oraz 13 grudnia 1982 r. rezerwiści podjęli dwie akcje protestacyjne w postaci odmowy przyjęcia posiłków ${ }^{66}$. Aby uniknąć konsekwencji za bezpodstawne odmówienie spożycia posiłku, wrzucano do zupy insekty (schwytane wcześniej w barakach mieszkalnych), które stawały się pretekstem do głodówki. Około 10-11 listopada 1982 r. na jednej z zewnętrznych ścian baraku za pomocą pasty do zębów wykonano napis "Solidarność". W dniu przysięgi planowano demonstracyjne „wystąpienie” w piżamach przy drodze dojazdowej do koszar. Akcję uniemożliwił nocny alarm i wielogodzinny wymarsz w głąb lasu na poligonie ${ }^{67}$.

Innym przejawem oporu było także sporządzenie, w drugiej połowie stycznia 1983 r. przez niektórych uczestników obozu kilkudziesięciu pamiątkowych plakietek z drewna brzozy z napisami „Wojskowy Ośrodek Odosobnienia Budowo 1982/83” czy „Solidarność” oraz świątecznych kartek pocztowych i kopert z napisami „Solidarność” (koperty zostały wykonane z kart używanych na strzelnicy). W ubikacjach malowane były symbole "S” z kotwicą. W noc sylwestrową z 1982 na 1983 r., z inicjatywy internowanego z Warszawy zorganizowano bieg sylwestrowy, który został przerwany interwencją uzbrojonego dyżurującego patrolu.

$\mathrm{Z}$ jednej z relacji wynika, że w trakcie próby zorganizowania upokarzającej musztry w postaci czołgania się dowódca oddał kilka strzałów w powietrze, aby przestraszyć internowanych niechętnie stosujących się do poleceń ${ }^{68}$.

2 lutego 1983 r. (dzień zwalniania z obozu) zaskoczeniem dla internowanych było dokonanie wobec nich rewizji ${ }^{69}$. Przeszukiwania prowadził oficer kontrwywiadu wojskowego. Jedną z przyczyn rewizji były informacje o pamiątkach wykonywanych przez internowanych. W trakcie takiej rewizji przy opuszczaniu jednostki przy Waldemarze Koziarku z Warszawy znaleziono pamiątkową, drewnianą plakietkę. Przyczynił się do tego ppor. Henryk Chorzewski, zastępca

\footnotetext{
Ibidem, s. 41.

65 R. Sawinski, J. Leszczełowski, op. cit., s. 166.

${ }_{66}$ M. Dąbrowski, Wojskowe obozy..., s. 41.

67 Ibidem.

68 Ibidem.

69 R. Sawinski, J. Leszczełowski, op. cit., s. 166.
} 
dowódcy kompanii rezerwy ds. politycznych, który zauważył, że Koziarek próbuje ukryć przy sobie plakietkę, i poinformował o tym oficera kontrwywiadu wojskowego ${ }^{70}$.

Tego samego dnia, za „pośrednictwem” żołnierza kierowcy ze służby zasadniczej odwożącego internowanych na stację kolejową, w ręce WSW wpadło sześć kolejnych egzemplarzy pamiątkowych plakietek. Kierowca miał przemycić drewienka, powierzone mu przez Zbigniewa Grucę z Lublina i Andrzeja Sarbę ze Skarżyska-Kamiennej, na stację kolejową w Złocieńcu, na którą odwoził grupki internowanych ${ }^{71}$. Nie jest jasne, czy kierowca przekazal powierzony pakunek WSW ze względu na swoją nadgorliwość, czy zmusiła go do tego sytuacja, ponieważ jego kontakt $\mathrm{z}$ internowanymi został zauważony przez kaprala służby zawodowej nazwiskiem Pańków, który powiadomił o tym wspomnianego już ppor. Chorzewskiego $^{72}$. Kierowca rozpoznał twarze Grucy i Sarby na podstawie okazanych książeczek wojskowych. W efekcie trzech wymienionych internowanych zostało zatrzymanych przez WSW.

Zatrzymanych początkowo umieszczono w Areszcie Garnizonowym w Koszalinie. 4 lutego 1983 r. Wojskowa Prokuratura Garnizonowa w Koszalinie, we współpracy z Oddziałem WSW w Koszalinie, wszczęła śledztwo przeciwko wszystkim trzem. Niektóre z przesłuchań prowadzone były w nocy. 18 lutego prokurator wojskowy przedstawił aresztowanym zarzuty popełnienia przestępstw zagrożonych karą od 3 do 5 lat więzienia. Co więcej, 12 lutego 1983 r., na prośbę śledczych z Koszalina, białostocka WSW przeprowadziła w ramach śledztwa przeszukanie w mieszkaniu byłego internowanego Tadeusza Sosnowskiego. Przyczyną tego były inicjały „S.T.” wyryte na jednym z drewienek, które 2 lutego 1983 r. wpadły w ręce WSW w Budowie ${ }^{73}$.

21 lutego 1983 r. sprawa została przekazana przez Wojskową Prokuraturę Garnizonową w Koszalinie do Prokuratury Wojewódzkiej w Koszalinie, która uznała, że 2 lutego, a więc przed wniesieniem aktu oskarżenia, internowani zostali już zwolnieni ze służby, a wobec tego nie podlegają władzy sądów wojskowych. 21 lutego internowanych przewieziono do Aresztu Śledczego w Szczecinku, a 28 lutego przekazano Prokuraturze Rejonowej w Drawsku Pomorskim. 3 marca prokurator zadecydował o uchyleniu tymczasowego aresztu. 7 marca 1983 r. Gruca, Koziarek i Sarba zostali wypuszczeni na wolność, a 11 maja 1983 r. decyzją Prokuratury

\footnotetext{
M. Dąbrowski, Wojskowe obozy..., s. 42.

Ibidem.

Ibidem.

73 Ibidem, s. 43.
} 
Rejonowej w Drawsku Pomorskim śledztwo zostało umorzone wobec „niestwierdzenia czynu przestępczego"74.

\subsection{Chelmno Nad Wiseą}

Obóz zlokalizowany był na poligonie wodnym JW 1636 Chełmno nad Wisłą (teren zalewowy zwany Kępą Panieńską) i funkcjonował w ramach 9 Pomorskiego Pułku Pontonowego. Od 5 listopada 1982 r. do 2 lutego 1983 r. przydzielono tu 304 osoby z ówczesnych województw: włocławskiego, toruńskiego, szczecińskiego, słupskiego, płockiego, olsztyńskiego, łódzkiego, koszalińskiego, gdańskiego, elbląskiego i bydgoskiego. Żołnierze rezerwy zostali podzieleni na pięć kompanii, a nie - jak nakazywał rozkaz - na cztery ${ }^{75}$. Służby wojskowe rozpowszechniły wśród mieszkańców Chełmna plotkę, że w obozie przebywają groźni przestępcy ${ }^{76}$. Od razu po przybyciu do obozu rezerwiści zostali ostrzyżeni i postawieni przed lekarzem. Większość z nich miała kat. $\mathrm{D}$, a nawet $\mathrm{E}^{77}$. Wśród powołanych znalazła się osoba, która nosiła gorset ortopedyczny, a inna była na wózku inwalidzkim ${ }^{78}$.

W skład komisji, która miała sprawnie zajmować się internowaniem pod pozorem ćwiczeń wojskowych, wchodzili: mjr Ryszard Chodynicki, mjr Tadeusz Małolepszy, mjr Mieczysław Derdowski, kpt. Ryszard Sobczak, kpt. Marian Gosz i kpt. Andrzej Ługowski. Bezpośredni kontakt z rezerwistami miał mjr Marian Łuczak odpowiedzialny za zorganizowanie obozu na poligonie wodnym w Chełmnie, dowódca 9 Pomorskiego Pułku Pontonowego. Jego zastępcą do spraw politycznych był mjr Aleksander Kopystecki ${ }^{79}$.

Po pięciu dniach pobytu w wojskowych koszarach w Chełmnie internowanych zakwaterowano na terenie położonego pod miastem poligonu Kępa Panieńska, gdzie przebywali do 24 grudnia 1982 r. Poligon znajdował się między wałem przeciwpowodziowym a Wisłą, na terenie zalewowym. Panowały tu skrajnie uciążliwe warunki życiowe. Rezerwistów ulokowano w namiotach mieszczących 8-12 osób, ogrzewanych przy pomocy metalowych piecyków („kóz”), których wolno było używać tylko od godziny 17 do 5. Na zmianę pełniono przy nich całonocne dyżury.

74 IPN Sz 265/15, Akta tymczasowego aresztowania. Zbigniew Gruca. Zakład Karny w Szczecinku; IPN Sz 270/1, Akta śledztwa Prokuratury Rejonowej w Drawsku Pomorskim w sprawie Władysława Koziarka, Zbigniewa Grucy i Andrzeja Sarby; IPN Sz 270/2 t. 1-2, Akta śledztwa Prokuratury Rejonowej w Drawsku Pomorskim w sprawie Wacława Koziarka, Zbigniewa Grucy i Andrzeja Sarby.

75 Trzystu z Kępy Panieńskiej (c.d.), na stronie http://www.darpoint.pl/CHELMNO/Chelmno_2.htm (8 I 2016).

76 M. Dąbrowski, Wojskowe obozy..., s. 44.

77 „Toruński Informator Solidarności” 1983, nr 43 (12 I), s. 2.

78 Trzystu z Kępy Panieńskiej (c.d.).

79 Ibidem. 


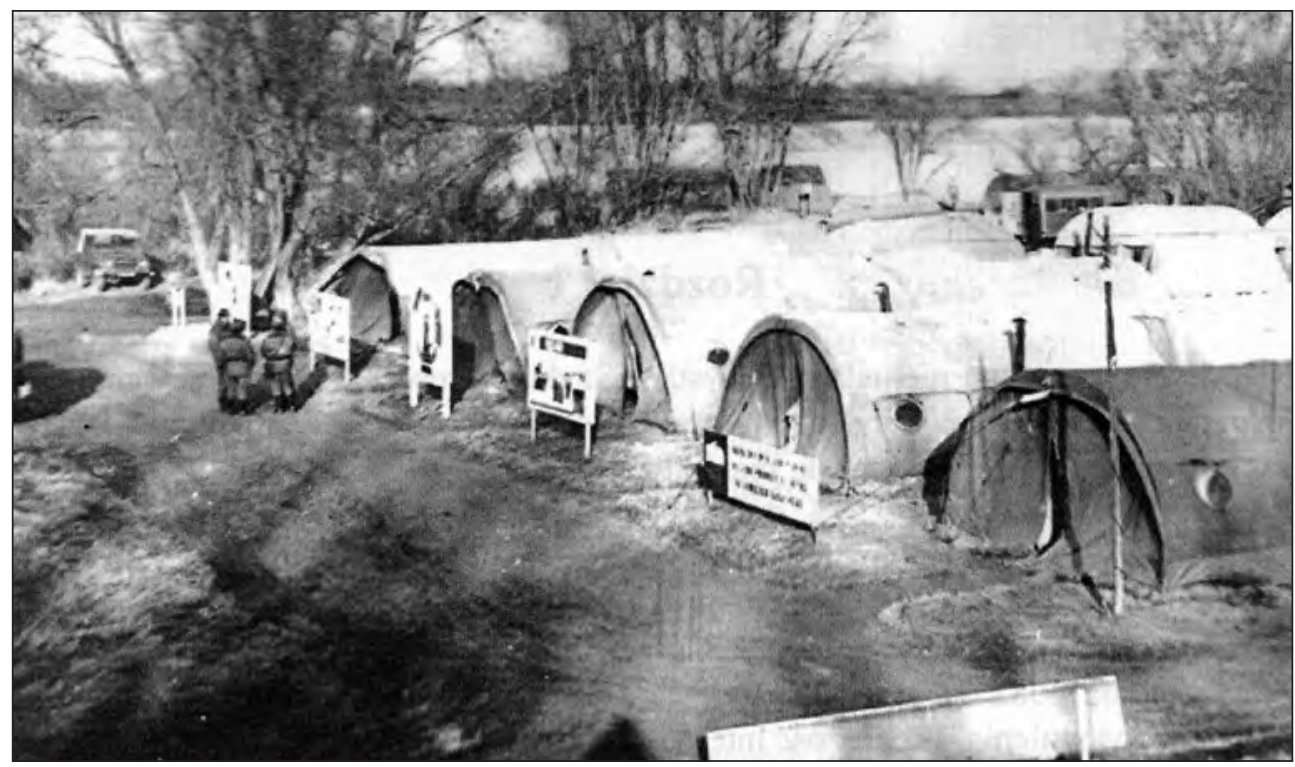

Zakwaterowanie internowanych „żołnierzy” w obozie w Chełmnie nad Wisłą

Żołnierze rezerwy angażowani byli do ciężkich prac (kopanie rowów, usuwanie zarośli) w niekorzystnych warunkach pogodowych. Tego typu prace fizyczne trwały nawet 10 godzin dziennie. $Z$ powodu katorżniczej pracy i tragicznych warunków bytowych wielu rezerwistów (dotyczyło to zwłaszcza osób nieprzystosowanych do służby wojskowej) trafiało na izbę chorych lub do szpitala wojskowego (w Grudziądzu). Zachorowalność sięgała niekiedy $80 \%{ }^{80}$. Do obozu trafił też „rezerwista" wcześniej internowany w ośrodku w Kwidzynie i tam dotkliwie pobity, $\mathrm{z}$ uszkodzonym kręgosłupem ${ }^{81}$. Jak bardzo ciężkie były prace wykonywane przez rezerwistów, doskonale obrazuje fakt, że czterem osobom zlecano przetransportowanie ok. $600 \mathrm{~kg}$ elementów mostu pontonowego. Po tego typu zadaniach lekarze wydawali zwolnienie od pracy przy pomocy kilofów. Zaświadczenie nie przewidywało jednak pracy przy pomocy łopat, więc dowódcy kierowali takie osoby już następnego dnia z powrotem do ciężkich zajęćs2.

W obozie nie było odpowiednich warunków sanitarnych, m.in. brakowało bieżącej i ciepłej wody oraz opieki lekarskiej. W każdą niedzielę internowanych przewożono do koszar w Chełmnie, gdzie mogli skorzystać z pryszniców, zaś na co dzień korzystali z miski z zimną wodą. Jednego dnia przy bramie koszar odbywały się widzenia $\mathrm{z}$ bliskimi. Podczas nich obecni musieli być oficerowie. Ze

80 M. Dąbrowski, Wojskowe obozy..., s. 44.

81 „Toruński Informator Solidarności” 1983, nr 43 (12 I), s. 2.

82 Fundacja Centrum Dokumentacji Czynu Niepodległościowego w Krakowie (dalej: FCDCN), „Niepokorni w kamasze", TVP SA 2009, reż. M. Palczewski. 
wspomnień Pawła Darnowskiego wiemy, że rodziny „żołnierzy” trzymano wcześniej przez wiele godzin przed bramą na mrozie, nawet bez możliwości skorzystania $\mathrm{z}$ toalet. W wielu wypadkach przybyłym rodzinom odmawiano widzeńn ${ }^{83}$. Widzenia $\mathrm{z}$ bliskimi początkowo trwały 15 minut, potem pół godziny, dopiero po czterodniowym proteście głodowym zezwolono na dłuższe spotkania ${ }^{84}$. Kadra zarządziła jednak, że rodziny przybywające z Gdańska i Szczecina nie będą dopuszczane do wizyt $\mathrm{z}$ internowanymi ${ }^{85}$. Korespondencja funkcjonowała $\mathrm{z}$ dużym opóźnieniem i była poddawana cenzurze.

Internowani poddawani byli upokarzającym procedurom. Po przybyciu do jednostki zostali rozebrani z cywilnych ubrań do naga, następnie ostrzyżono ich i objęto „rozmowami ostrzegawczymi”. Na początku pobytu związkowcom poodbierano także przedmioty kultu religijnego.

Wobec żołnierzy rezerwy stosowano psychiczny terror. Przez cały czas byli oni poddawani przesłuchaniom. Podczas ich nieobecności w namiotach, w których byli zakwaterowani, przeprowadzano rewizje. Wymierzano bardzo surowe kary aresztu, przedłużające pobyt na „ćwiczeniach”, nawet za drobne niedociągnięcia. $\mathrm{Na}$ terenie obozu uruchomione były głośniki radiowozu wojskowego, z których nadawano komunikaty w celu indoktrynacji. Obowiązkiem było oglądanie wieczornego „Dziennika Telewizyjnego”.

Internowanym nie udzielano przepustek. Tylko w dwóch przypadkach pozwolono na urlopy okolicznościowe trwające 48 godzin $^{86}$. Rozmieszczone warty żołnierzy służby zasadniczej oraz kilkakrotne $\mathrm{w}$ ciągu dnia grabienie przez służbę dyżurną drogi gruntowej otaczającej obóz miały zapobiec ucieczkom i wymykaniu się z obozu. Na początku pobytu jeden $\mathrm{z}$ internowanych wydostał się z terenu jednostki i przekazał informacje o warunkach panujących w niej proboszczowi kościoła farnego w Chełmnie - ks. Janowi Kujaczyńskiemu ${ }^{87}$. Proboszcz próbował interweniować w sprawie warunków bytowych panujących w obozie oraz we współpracy z wikarym ks. Czesławem Rajdą zorganizował zbiórkę leków i żywności. Ponadto za pośrednictwem kurii biskupiej informacje o wojskowym obozie specjalnym w Chełmie trafily do Radia Wolna Europa ${ }^{88}$. Tego typu pomoc okazały również lokalne środowiska „Solidarności”, które początkowo nie ufały internowanym. 20 grudnia 1982 r. w nocy żywność na kajakach przywieźli klerycy

\footnotetext{
Trzystu z Kępy Panieńskiej (c.d.).

W. Polak, Czas ludzi niepokornych, Toruń 2003, s. 98.

„Toruński Informator Solidarności” 1983, nr 42 (2 I), s. 2.

M. Dąbrowski, Wojskowe obozy..., s. 45.

W. Polak, op. cit., s. 99.

38 „Dziennik Łódzki” 2009, nr 225 (25 IX), s. 21.
} 
z seminarium w Pelplinie ${ }^{89}$. Również taksówkarze regularnie przekazywali osobom przyjeżdżającym na widzenia do jednostki paczki z jedzeniem i witaminami ${ }^{90}$.

W trakcie pobytu na poligonie grupę liczącą 30 osób przetransportowano mostem pontonowym na inny poligon w okolicy Kwidzyna. Było to bardzo niebezpieczne zadanie, ponieważ zarządzono trzydniowy alarm i kazano rezerwistom w nocnych warunkach budować przeprawę przez rzekę. Stanowiło to bezpośrednie zagrożenie życia, zwłaszcza dla osób nieprzystosowanych do tego typu zadań ${ }^{91}$. W pobliżu mostu utworzono nawet drugi obóz namiotowy z kuchnią polową. Zgrupowani w nim internowani angażowani byli do konserwacji sprzętu pontonowego.

11 listopada internowani podjęli głodówkę w odpowiedzi na pierwszą rewizję przeprowadzoną w namiotach. Aby przerwać głodówkę, jedna z kompanii została wywieziona do lasów w okolicach Kwidzyna. 15 listopada nad obozem internowani powiesili wykonaną prowizorycznie flagę z napisem „Solidarność”.

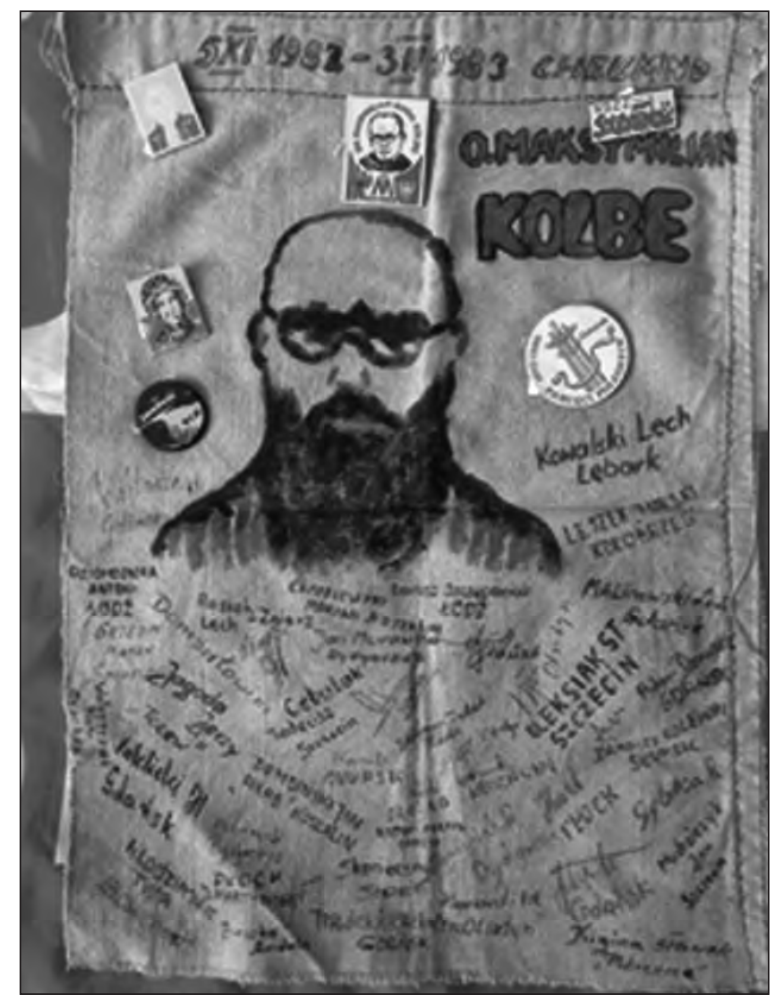

Pamiątkowa makatka $\mathrm{z}$ obozu internowanych w Chełmnie nad Wisłą

\footnotetext{
89 M. Dąbrowski, Wojskowe obozy..., s. 45.

90 Trzystu z Kępy Panieńskiej (c.d.).

91 FCDCN, „Niepokorni w kamasze”, TVP SA 2009, reż. M. Palczewski.
} 
Na terenie obozu dwukrotnie wykonano duże krzyże. 27 listopada ułożony został krzyż z kamieni, zaś w nocy z 12 na 13 grudnia, korzystając z dogodnych warunków pogodowych (gęsta mgła), pośrodku obozu postawiono brzozowy krzyż, przy którym podczas porannego apelu odśpiewano „Nie rzucim ziemi”. Na polecenie kadry jednostki oba krzyże zostały natychmiast usunięte. Symbole religijne (krzyże, różańce, medaliki, obrazki), wieszane przez internowanych przy ich łóżkach w namiotach, były usuwane przez kadrę ${ }^{92}$. Mimo to wieczorami w namiotach prowadzono zbiorowe modlitwy oraz śpiewanie pieśni religijnych i patriotycznych. Internowani wykonywali okolicznościowe pieczątki „Wojskowy Obóz Internowanych Solidarność Chełmno” i „Poczta Internowanych Chełmno”"93.

W dniu wyjazdu internowanych poddano rewizji osobistej, a następnie małymi grupami rozwożono do okolicznych stacji kolejowych (Kornatowo, Terespol Pomorski).

\subsection{CZARne}

Obóz zlokalizowany był na terenie JW nr 2198 w Czarnem na Pomorzu Zachodnim koło Szczecinka (województwo słupskie). Podczas II wojny światowej mieścił się tu obóz jeniecki dla żołnierzy Armii Czerwonej, obecnie natomiast znajduje się tu więzienie ${ }^{94}$. Trafiło tutaj 77 osób, głównie z województw: warszawskiego, lubelskiego i białostockiego. Została z nich utworzona kompania rezerwistów. Po przybyciu do koszar internowani zostali poddani strzyżeniu, jak poborowi służby zasadniczej. Zajmowali trzy sale w jednym z budynków koszar, odizolowanym od reszty jednostki. Kadra jednostki w Czarnem nie była niechętnie nastawiona do związkowców, wykonywała tylko rozkazy ${ }^{95}$. O charakterze obozu świadczy najlepiej fakt, że rezerwiści upomnieli się o przyznanie dystynkcji, które przywrócono im dopiero po dwóch lub trzech tygodniach ${ }^{96}$. Utworzone trzy plutony później przekształcono, tworząc pluton kaprali rezerwy ${ }^{97}$.

W ramach „ćwiczeń" przygotowujących do specjalizacji saperskiej rezerwistom zlecono wykonywanie prac wycinkowych w lesie (m.in. usuwanie drzew uszkodzonych w wyniku wybuchów pocisków podczas działań na poligonie). Największym problemem był brak możliwości wysuszenia ubrań i butów na kwaterach z powodu niewystarczającego ogrzewania koszar. Z tym problemem

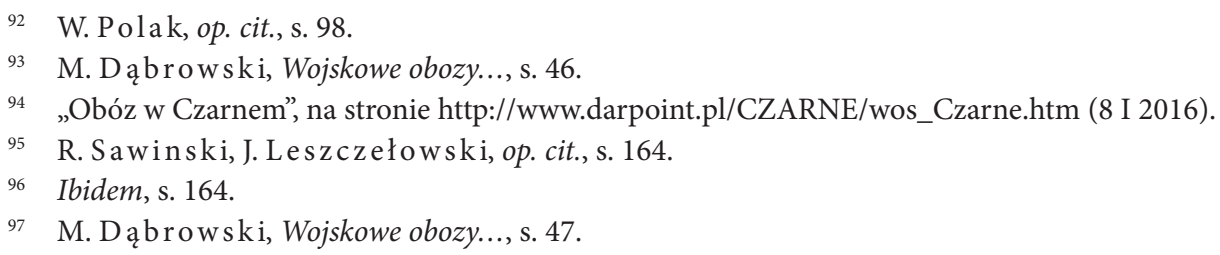


radzono sobie, susząc odzież podczas porannych ognisk w lesie. Ciężkie warunki pogłębiał także brak ciepłej wody.

Około 11 listopada 1982 r. podczas pobytu w jednostce internowani podjęli strajk głodowy. Bezpośrednią przyczyną było znalezienie myszy na podanym rezerwistom chlebie. Protest poskutkował zamknięciem stołówki i uruchomieniem kuchni polowej, w której odtąd przygotowywano posiłki. Od tego momentu żołnierze służby zasadniczej i internowani spożywali posiłki osobno ${ }^{98}$.

Umożliwiono, także chętnym internowanym, dwukrotne wysłuchanie radiowych transmisji niedzielnej mszy świętej. Gdy po drugiej transmisji internowani odśpiewali „Boże, coś Polskę” z tekstem „Ojczyznę wolną racz nam wrócić, Panie”, ukarano ich 30-kilometrowym marszem oraz odebraniem możliwości słuchania mszy. Z powodu początkowego braku nadzoru nad odbiornikiem radiowym przez pewien czas udało się słuchać audycji zachodnich. Gdy jednak dowództwo się o tym dowiedziało, odbiornik został przestrojony na odbieranie wyłącznie I programu Polskiego Radia z Warszawy.

Do obowiązków rezerwistów należało codzienne oglądanie wieczornego „Dziennika Telewizyjnego”. Aby uniknąć tej czynności, siadano tyłem do telewizora, a kilkakrotnie spowodowano nawet spięcie prądu w budynku. Z prawdziwym entuzjazmem przyjęto jedynie telewizyjne relacje dotyczące śmierci i pogrzebu sowieckiego przywódcy Leonida Breżniewa.

Praktykowano przesłuchania aktywnej części internowanych przez oficera politycznego. Pewnego dnia urządzono rewizję, podczas której wśród rzeczy osobistych jednego z internowanych WSW znalazła podziemne biuletyny „Solidarności". Osoba, u której znaleziono materiały, została wywieziona z jednostki i osadzona $\mathrm{w}$ areszcie. Po tym incydencie część internowanych była przesłuchiwana przez oficerów WSW oraz kilkakrotnie powtórzono przeszukiwanie rzeczy internowanych pod ich nieobecność. Aby zapobiec nieprzyjemnym dla kadry sytuacjom, w dniu przysięgi wojskowej służby zasadniczej rezerwistów wywieziono z koszar na całodniową wycieczkę autokarową po Wale Pomorskim. 11 listopada 1982 r. ściągnięto pewną liczbę czołgów i transporterów opancerzonych, aby urządzić internowanym pokaz siły.

Po miesiącu dowództwo zgodziło się na pierwsze odwiedziny ze strony rodzin i bliskich rezerwistów. Wcześniej rodzinom przybywającym pod bramę jednostki udzielano informacji, że poszukiwanych przez nich osób nie ma w koszarach (np. wyjechały na poligon). Podczas spotkań z bliskimi rezerwistom towarzyszyli dyżurni ze służby zasadniczej. Znamiennym przykładem stosunku do

98 Ibidem, s. 47-48. 
internowanych było nieudzielenie przepustki Jackowi Firkowskiemu w związku z operacją żony. Pozwolono mu jedynie wyjść do miasta w celu skorzystania $\mathrm{z}$ budki telefonicznej, ale pod nadzorem uzbrojonego żołnierza ${ }^{99}$.

Czasem miały miejsce groteskowe sytuacje, np. gdy próbowano zmusić internowanych do maszerowania na stołówkę z pieśnią na ustach, w takt kroku marszowego zaśpiewano „Widziałem Marynę raz we młynie”. Podobny charakter miała kara zapisania 60-kartkowego zeszytu nazwami wszystkich republik sowieckich, nałożona przez oficera politycznego na jednego z internowanych, po tym jak podczas pogadanki politycznej żołnierz związkowiec zakwestionował oficjalną liczbę republik, dodając jeszcze ówczesną Polskę Ludową. W przepisywanie zeszytu solidarnie zaangażowała się większa grupa internowanych ${ }^{100}$.

Internowanych jeszcze kilka dni przed opuszczeniem jednostki trzymano w niepewności w sprawie tego, czy zgodnie z przepisami zostaną zwolnieni po trzech miesiącach „ćwiczeń”. Przy opuszczaniu koszar rezerwiści zostali w upokarzający sposób poddani rewizji osobistej, podczas której musieli rozebrać się do naga ${ }^{101}$. Znalezione „podejrzane” materiały były konfiskowane. Internowanych rozwożono w niewielkich grupach, liczących do pięciu osób, na różne stacje kolejowe ${ }^{102}$.

\begin{abstract}
The Army as Internment: Forms of the Repression During the Martial Law in the Years 1982-1983 Against Activists of the Anticommunist Opposition Placed in Military Special Camps (Part I)

The work focuses its issues on one of the repression forms used in the martial law introduced on 13th December 1981 to pacify the society which tried to change the fossilised communist system through activity in the Independent Self-Governing Trade Union "Solidarity". It was not a new solution in the Polish People's Republic - just after the Second World War the communist authority drafted into "alternative military service" opponents of sovietisation of the country, directing them to forced labour in mines. Fearing a social rebellion before the second anniversary of the independent trade union registration, communist authorities interned in military special camps, functioning in Poland from 5 November 1982 to 3 February 1983, 1450 trade union activists and members of the political parties unaccepted by communists. 264 younger colleagues of these people were drafted into the basic military service lasting two years in three units intended for this purpose.
\end{abstract}

\title{
KEYWORDS
}

martial law in Poland in the years 1981-1983, military special camps, repression of the martial law, NSZZ Solidarity, anticommunist activity, Brzeg, Budowo, Chełmno on the Vistula River, Czarne

99 R. Sawinski, J. Leszczełowki, op. cit., s. 164.

100 M. Dą browski, Wojskowe obozy..., s. 49.

101 R. Sawinski, J. Leszczełowki, op. cit., s. 164.

102 M. Dąbrowski, Wojskowe obozy..., s. 49.

* Bibliografia do niniejszego artykułu zostanie zamieszczona w drugiej części tekstu, która ukaże się w następnym numerze czasopisma - przyp. red. 